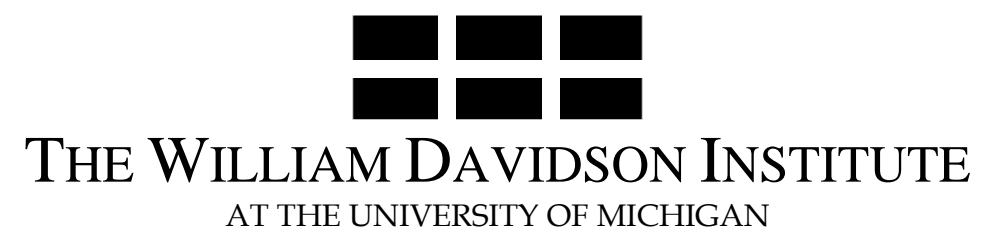

AT THE UNIVERSITY OF MICHIGAN

\title{
CORPORATE GOVERNANCE, MANAGERS' INDEPENDENCE, EXPORTING AND PERFORMANCE OF FIRMS IN TRANSITION ECONOMIES
}

By: Igor Filatotchev, Natalia Isachenkova and Tomasz Mickiewicz

William Davidson Institute Working Paper Number 805

November 2005 


\title{
CORPORATE GOVERNANCE, MANAGERS' INDEPENDENCE, EXPORTING AND PERFORMANCE OF FIRMS IN TRANSITION ECONOMIES
}

\author{
Igor Filatotchev* \\ Department of Management \\ King's College London \\ 150 Stamford Street, London SE1 9NN, UK \\ Tel/Fax: +44(0)20 78483965 \\ e-mail: igor.filatotchev@kcl.ac.uk \\ Natalia Isachenkova \\ School of Accounting \& Finance \\ Kingston University \\ Kingston Hill, Kingston upon Thames, Surrey, KT2 7LB, UK \\ Tel: $+44(0) 2085478206$ \\ Fax: $\quad+44(0) 2085477026$ \\ e-mail: n.isachenkova@kingston.ac.uk \\ Tomasz Mickiewicz \\ Department of Social Sciences, SSEES, \\ University College London \\ Gower St., London WC1E 6BT, UK \\ Tel. +44(0)20 78628606 \\ Fax: +44(0)20 78628642 \\ e-mail: t.mickiewicz@ucl.ac.uk
}

This version: February 2006

\footnotetext{
* Corresponding author. This project was supported by research grants from the European Commission (Phare ACE Programme P98-1048-R) and the MC Grabowski Fund. We express our gratitude to the sponsors. We also take exclusive responsibility for all the opinions expressed in this study. We thank the participants of the Academy of Management Annual Meeting (Honolulu, August 2005), $4^{\text {th }}$ International Workshop “Transition and Enterprise Restructuring in Eastern Europe” (Copenhagen Business School, August 2004) and seminars at the London Business School and King's College London for their comments on earlier versions of this paper. We are grateful to Piotr Kozarzewski, Peter Vince, Kate Bishop and Beata Manthey for their research assistance.
} 


\section{CORPORATE GOVERNANCE, MANAGERS' INDEPENDENCE, EXPORTING AND PERFORMANCE OF FIRMS IN TRANSITION ECONOMIES}

\section{[Abstract]}

Using data on 157 large companies in Poland and Hungary this paper employs a Bayesian structural equation modeling to examine interrelationships between corporate governance, managers’ independence from owners in terms of strategic decision-making, exporting and performance. It is found that managers' independence is positively associated with firms' financial performance and exporting. In turn, the extent of managers' independence is negatively associated with ownership concentration, but positively associated with the percentage of foreign directors on the firm's board. We interpret these results as an indication that (i) concentrated owners tend to constrain managerial autonomy at the cost of the firm's internationalization and performance, (ii) board participation of foreign stakeholders, on the other hand, enhances the firm's export orientation and performance by encouraging executives’ decision-making autonomy.

JEL Codes: G32 G34 L21 L22 L25 P31

Key words: corporate governance, strategic independence, exporting, performance 


\section{CORPORATE GOVERNANCE, MANAGERS' INDEPENDENCE, EXPORTING AND PERFORMANCE OF FIRMS IN TRANSITION ECONOMIES}

\section{Introduction}

Economic reforms and globalization of firms in transition economies ${ }^{1}$ have dramatically changed the boundaries and content of governance and strategy of firms exposing them to multipoint competitive pressures. Managers of these firms have to make strategic decisions in the complex decision-making environment (Sanders and Carpenter, 1998), and one should expect that the performance of large firms may be closely linked with managerial flexibility in making strategic decisions within the context of the firm's governance. Yet this issue remains relatively unexplored. Emphasis on organizational and environmental factors as antecedents of both financial performance and export performance ignores possible organizational effects of managers' strategic independence defined as their autonomy in strategic decision making and absence of direct interference and constraints imposed by the owners (Newman, 2000); the situation, which enable the managers to provide timely and effective strategic responses in a rapidly changing environment (Harrigan, 1985, Mahoney, 1995). In addition, little is known about the impact of emerging corporate governance mechanisms on managerial strategic independence, although previous research suggests that this may be an important

\footnotetext{
${ }^{1}$ In this paper, we define transition economies (countries) as countries of Central Eastern Europe and the Commonwealth of Independent States. For more details, see for instance: Mickiewicz, 2005. We leave aside the interesting issue of applicability of the term 'economic transition' to other economies, East Asian in particular.
} 
antecedent of managerial ability to undertake performance-enhancing strategies (Hoskisson et al., 2000).

The perspective adopted in this paper is that well-functioning, market-based systems of corporate governance leave the key business decisions in the hands of professional managers, while owners make managers accountable by using various governance mechanisms, such as board monitoring and control. In contrast, insufficient managerial independence in the transition countries driven by the characteristics of the legal framework of corporate governance and legacy of privatization strategies, may have negative implications for performance.

Correspondingly, this study explores the links between corporate governance, managers’ strategic independence, financial performance and export performance of large firms in two economically important transition countries, Poland and Hungary. Before their economic reforms, exporting remained the monopoly of a handful of specialized state-owned companies. In the liberalized economic environment, with sluggish internal demand, adopting export-oriented strategies may be closely linked to better financial performance of the firm (Luo and Peng, 1999). In this environment, how do private enterprises develop exporting? We address this broad question by examining three specific issues. First, how does the freedom for management to exercise strategic choice affect export orientation, approximated by both level and change in exports as a proportion of total sales? Second, what are possible links between these factors and financial performance? And finally, how is managerial independence in terms of strategic decisions affected by corporate governance characteristics of firms in transition countries? 
Our study makes a number of contributions. We provide a new framework modelling the linkages between managers' strategic independence, governance factors, exporting and financial performance. Research in this area has been thin and a major barrier has been the complex interdependence of governance, strategies and performance. While previous research has linked strategies with performance (Hoskisson et al., 2000; Makhija, 2004), and governance directly with performance (Djankov and Murrell, 2002; Peng, 2004), this paper takes the full governance-strategy-performance paradigm and makes a novel contribution by applying Bayesian-based structural equation modeling (SEM) to the inter-relationships between governance factors, managers’ independence, exporting strategy and financial performance. To verify our theoretical assumptions, we use a multi-industry sample of 157 large, private, non-financial firms.

\section{Theoretical framework and research hypotheses}

Economic reforms in Central and East Europe (CEE) introduced during the 1990s aimed at increasing enterprise efficiency and making their products internationally competitive. Reforms were accompanied by a structural crisis, exacerbated by the collapse of the East European trading bloc and the break-up of the USSR (Uhlenbruck et al., 2003). The initial (pre-reform) situation of import protection and export promotion through monopolistic, state-owned foreign trade companies meant enterprises were illequipped to meet overseas threats and had different opportunities for internationalization.

Liberalization and privatization were designed to eliminate the constraints on the independent managerial decision-making process imposed by state ownership and the 
command-economy system (Hoskisson et al., 2000; Makhija, 2004). In the case of Hungary and Poland, companies were privatized using a wide range of methods, with a significant participation of institutional corporate investors, including multinationals (Djankov and Murrell, 2002). These privatizations resulted in a diverse range of ownership structures and corporate governance mechanisms (Newman, 2000).

It has been acknowledged in previous research that corporate governance affects enterprises restructuring and financial performance (Hoskisson et al., 2000; Peng, 2004), while the effects of governance on exporting are less clear. Therefore, transition economies are a natural context to test theories concerning the first stage of internationalization, i.e. direct exporting (Andersen, 1993; Aulakh et al., 2000).

Our study is based on the strategic management perspective, with export intensity and financial performance being the outcome of a multi-dimensional strategic decisionmaking process. This process is driven by the firm's managers' strategic independence, which is defined as "an ability to respond to various demands from dynamic competitive environments” (Sanchez, 1995, p. 138). When managers are not constrained by owners in terms of their strategic decisions, they are able to take timely actions aimed at improving the firm's competitive position in domestic markets and promoting overseas outputs (Aulakh et al., 2000). By being involved in international activities, firms in transition economies may develop further their capabilities (Sanders and Carpenter, 1998), and this suggests a positive relationship between exporting and financial performance (Luo and Peng, 1999).

Although performance and export orientation in particular may be increased by higher degrees of managerial decision-making autonomy, the latter, in turn, depend on 
the firm's governance factors such as ownership structure and board composition (Uhlenbruck et al., 2003; Hoskisson et al., 2000). Therefore, our framework suggests that the complex relationships between governance, exporting performance and financial performance are mediated by managers’ strategic independence. The following sections discuss these issues in detail.

\subsection{Managers'strategic independence, export orientation and performance}

Institutional and economic reforms and internationalization of transition economies such as Poland and Hungary imposed new demands on local firms to develop their dynamic capabilities that enable them to take advantage of new opportunities, including gaining access to new product markets (Hoskisson et al., 2000; Newman, 2000). Uhlenbruck et al. (2003) strongly emphasize that the continuously changing market conditions in transition economies require the development of "strategic flexibility" that should help firms to take advantage of existing and new strategic opportunities. Strategic flexibility depends jointly on the inherent flexibility of resources available to the organization (Finney et al., 2005) and on managers' “flexibility in coordinating the use of resources” (Sanchez, 1995, p. 138).

The importance of "resource flexibility" has been acknowledged in previous research (Harrigan, 1980; Mahoney, 1995). For example, resource-based view considers the organization's capacity to change as a function of such firm characteristics as capital "specificity”, “slack” resources, the firm's diversity defined in terms of product

diversification and/or organizational structure (Finney et al., 2005; Hitt et al., 1998). 
However, firms in transition economies inherited from their central planning past a bundle of resources, which are inconsistent with the requirements of effectiveness in a market economy (Uhlenbruck et al., 2003). Therefore, in the transition environment, another component of the firm's flexibility, managerial strategic independence, or their ability to make bold and timely decisions over capability-enhancing strategies without restrictions imposed by new owners of privatized firms, may become particularly important. In command economies, managerial initiatives were constrained by direct orders from the planning bureaucracy (Kornai, 1980). New private owners of firms in Poland and Hungary were expected to unlock managerial talent, but with repeated institutional upheavals, organizational learning was difficult (Newman, 2000). Peng (2004) suggests that uncertainty and institutional changes in transition lead to a deepening mistrust between managers and "new principals", who may try assume full control over strategic decisions. To summarize, organizational outcomes of strategic restructuring in transition economies, such as the extent of internationalization and financial performance, may be impeded not only by constraints related to organizational resources, but also by a lack of managerial strategic independence, or their ability to use wider strategic options without restrictions imposed by new owners. Hence:

Hypothesis 1. The extent of managers' strategic independence is positively associated with export orientation.

Hypothesis 2. The extent of managers' strategic independence is positively associated with financial performance. 
International business research considers exporting and financial performance as interrelated organizational outcomes of the firm's strategic dynamics (Aulakh et al., 2000). Using sunk-cost arguments a number of authors suggest that financially betterperforming firms in an industry are more likely to be exporters (Bernard and Jensen, 1999; Clerides et al., 1998). There has been less research on whether there is a positive feedback from exporting to firm performance. International business research argues that internationalization enables firms to leverage their existing capabilities and knowledge across countries and create scale economies otherwise unavailable domestically (Andersen, 1993). Sanders and Carpenter (1988) suggest that being exposed to overseas markets helps the firm to respond more effectively to foreign competitors in their domestic market. Firms are continually searching for new technologies, new ways of organizing their operation, and firms can take advantage of new information gained by exporting that is also valuable when competing in their home market (Bernard and Jensen, 1999). Gains from export orientation may be particularly strong in transition economies, where firms could face limited opportunities at home ('push factor'). More importantly, given the low level of pre-reform international trade, substantial gains can result from taking advantage of external liberalization and export orientation ('pull factor'); the latter could become a key factor leading to improved financial performance (Luo and Peng, 1999). Hence:

Hypothesis 3. Export orientation is positively associated with financial performance. 


\subsection{Corporate governance and managers' strategic independence}

When there is an increase in information asymmetry between managers and owners that is related to the economic transition in general, and internationalisation of the firm in particular, outside owners may limit managers' “strategic freedom” (Makhija, 2004). In this environment, large shareholders have both the incentives and the means to restrain the strategic independence of managers (Zeckhauser and Pound, 1990). Moreover, lack of developed capital markets in CEE, limited portfolio diversification and liquidity mean that even when large shareholders recognize the potential upside of a particular business strategy, such as exporting, they are affected adversely by the company's idiosyncratic risk (Maug, 1998) and may chose to impose sub-optimal strategies on managers. And last but not least, large shareholders in countries with relatively low protection of minority investors, such as CEE, may attempt to take advantage of their power and realize "private benefits of control". This expropriation may take various forms, such as relatedparty transactions, use of transfer pricing, assets stripping and other forms of "tunnelling" of revenue and assets from firms (La Porta et al., 1997, 2000). Again, this suggests direct involvement of dominant owners in strategic decisions and less emphasis on performanceenhancing strategies that may benefit minority shareholders. We propose:

Hypothesis 4. The extent of managers' strategic independence is negatively associated ownership concentration. 
The composition of a firm's board of directors is another governance parameter that can affect the decision-making process, shaping the extent of managers' strategic independence (Baysinger and Hoskisson, 1990). Strategy research particularly emphasizes the importance of the board's service and strategic roles when the firm faces a highly uncertain environment of economic transition (Peng, 2004). For firms, which were until recently operating in the semi-autarchic environment, a particularly positive role in this respect may be played by the foreign directors, who supply critical information and advice otherwise unobtainable. Board members associated with foreign investors also improve monitoring capacity of the board and mitigates moral hazard costs associated with managerial decision-making autonomy. Therefore, presence of foreign board members may bring in new organizational culture, enhancing managers' strategic independence, and we suggest:

Hypothesis 5. The extent of managers' strategic independence is positively associated with the proportion of foreign directors on the firms' board.

\section{Research Methods}

\subsection{Sample}

Firm-level data was collected simultaneously in Poland and Hungary in 2001 using the same structured instrument (translated and back-translated from English into Polish and Hungarian, correspondingly). In the course of face-to-face interviews, company presidents and CEOs provided information on observable company 
characteristics and managers' assessment of their independence along eleven strategic dimensions (see below, Section 3.2), each reported on a 7-point Likert scale. Our surveys of Polish and Hungarian companies were conducted by the Research Department of the Polish Sociological Society jointly with CASE Institute (Warsaw), and by the Institute of Economics of the Hungarian Academy of Science respectively. To obtain representative samples of large companies, we defined the sample frame using two large company lists that are in public domain in Poland and Hungary. In Poland, we used a list of the 500 largest (in terms of sales) non-financial companies that is maintained by the Institute of Economics of the Polish Academy of Sciences and regularly published by the Rzeczpospolita. In Hungary, we used a list of the 250 largest companies available from the Figyelo magazine. These two lists were combined together, producing a sample frame for the survey. The average non-response rate in both countries was below $10 \%$. The survey generated 100 and 57 usable questionnaires in Poland and Hungary respectively. We verified the representativeness of our sample using available comparison criteria, such as size, age, industry affiliation, etc. A standard test of non-response bias indicated no significant differences between respondents and non-respondents on variables such as country and industry distributions, number of employees, etc. Concerned with inter-rater reliability, a randomly selected $5 \%$ of companies were re-visited by the interviewers. No deviations between the study data and companies' documents, such as payroll lists, share registers, etc. were identified.

\subsection{Measures and analysis}


We adopt the structural equation modeling (SEM) approach and estimate SEM parameters using Gibbs sampling, a simulation procedure based on the Markov chain Monte Carlo (MCMC) method, implemented in the Bayesian inference package WinBUGS (Spiegelhalter et al., 2000). The Bayesian SEM is a more robust research methodology because it circumvents the need to rely on asymptotic theory in the estimation procedures, which may be questionable when the sample size is small, and, therefore, inferences based on maximum likelihood estimates of SEM may be overconfident. Another advantage of the Bayesian method is a possibility to impute missing values associated with non-responses to the survey questions. (For details see: Gelman et al., 2004; Congdon, 2003; Gilks et al., 1996).

In the SEM we investigated the relationships between latent (unobservable) constructs for managerial independence $\left(\psi_{i}\right)$, export orientation $\left(\eta_{i}\right)$ and operating performance $\left(\xi_{i}\right)$ of a firm $i$. A graphical summary of the SEM is provided in Figure 1, where measurable indicators are in boxes and latent variables are in ovals. 
Figure 1. Structural Equation Model

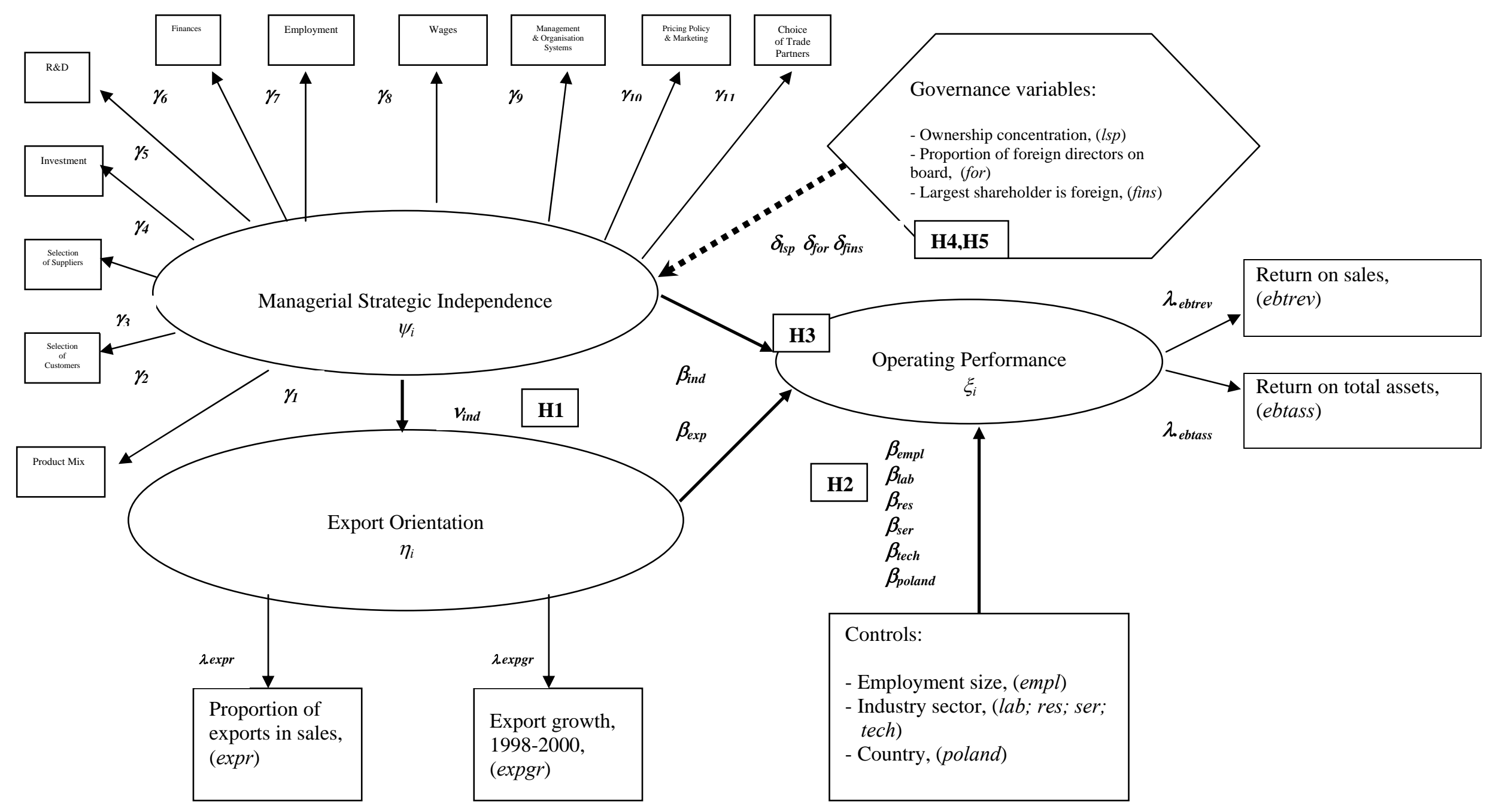


To develop managerial independence variable $\left(\psi_{i}\right)$ we used eleven ordinal indicators of the managerial independence $y_{k}$ generated by answers to scaled response questions with regard to how much independence management team has in deciding on: 1) product mix; 2) selection of customers; 3) selection of suppliers; 4) investment; 5) research and development; 6) finances; 7) employment; 8) wages; 9) management and organization systems; 10) pricing policy and marketing; 11) choice of trade partners. The answers were provided on a 7-point Likert scale with $1=$ decided by the owners (i.e. a local parent, foreign company, other institutional investors, etc.) and 7 = decided by the firm's executive team. The latent variable for export orientation $\left(\eta_{i}\right)$ was operationalized by using the proportion of export revenues to total sales for $2000\left(\operatorname{expr}_{i}\right)$ and the percentage change in export sales over the period of 1998-2000 $\left(\operatorname{expgr}_{i}\right)$. The latent variable of operating performance $\left(\xi_{\mathrm{i}}\right)$ is operationalized by earnings before taxes over assets (ebtass $)_{i}$ ) and earnings before taxes over sales revenue $\left(\right.$ ebtrev $\left._{i}\right)$ in 2000, although we recognize that both these measures have their own shortcomings. Similar measures have been widely used (Djankov and Murrell, 2002).

In terms of corporate governance characteristics, the ownership concentration measurement was based on information on the percentage of shares held by the largest shareholder. To take account of a possible non-linearity in ownership concentration effects, we considered four ownership intervals of less than $25 \%, 25-49 \%, 50-74 \%$ and 75-100\%. Thus, the ownership concentration was represented by a four-fold categorical variable $\left(l s p_{i}\right)$ defining ownership intervals. The extent of foreign representation on the board was measured by the proportion of foreign directors on board $\left(f o r_{i}\right)$. To control for 
the possible effect of the identity of the largest shareholder, we also introduced a dummy variable for the largest shareholder being a foreign firm $\left(\right.$ fins $\left._{i}\right)$.

Finally, we also considered a number of firm-, industry- and country-level factors that may affect performance (see Figure 1). To control for the firm's size in terms of employment, we used three dummies ( $x_{i, e m p l,}$ ) for intervals of (250-499), (500-999) and (above 1000) of employees respectively. The (below 250) interval was used as a control. Four sector dummies $\left(x_{i, \text { sector }}\right)$ were used for labor-intensive (ISIC codes 15-20 and 36), resource-intensive (ISIC codes 21-26), high-tech (ISIC codes 28-35), services and construction (ISIC codes 45, 50-52, 55) industries, with firms from heavy industry (ISIC: $<14$ and 27) being used as a control. A dummy variable $\left(x_{i, p o l a n d}\right)$ was used for companies in Poland.

The Bayesian model includes two parts: (i) a set of measurement equations that provide links between the manifest variables discussed above and the three latent constructs, and (ii) structural equations which verify the relationships between the latent constructs $\left(\psi_{i}, \eta_{i}, \xi_{\mathrm{i}}\right)$, as well as analyze the effects of governance parameters on managerial independence $\left(\psi_{i}\right)$. We estimated the following SEM, with the following structural equations:

$$
\begin{aligned}
& \xi_{i}=\alpha+\beta_{\text {ind }} \psi_{i}+\beta_{\text {exp }} \eta_{i}+\beta_{\text {empl }} x_{i \text {,empl }}+\beta_{\text {sector }} x_{i, \text { sector }}+\beta_{\text {poland }} x_{i, \text { poland }} \\
& \eta_{i}=k_{1}+v_{\text {ind }} \psi_{i} \\
& \psi_{i}=\mathrm{k}_{2}+\delta_{\text {lsp }} l s p_{i}+\delta_{\text {fins }} \text { fins }_{i}+\delta_{\text {for }} f o r_{i}
\end{aligned}
$$

and measurement equations given by: 


$$
\begin{aligned}
& \text { ebtrev }_{i}=k_{3}+\lambda_{\text {ebtrev }} \xi_{i} \\
& \text { ebtass }_{i}=k_{4}+\lambda_{\text {ebtass }} \xi_{i} \\
& \operatorname{expr}_{i}=k_{5}+\lambda_{\text {expr }} \eta_{i} \\
& \operatorname{expgr} r_{i}=k_{6}+\lambda_{\text {exgr }} \eta_{i} \\
& \operatorname{logit}\left\{\operatorname{Pr}\left(y_{i k} \leq j_{k}\right)\right\}=\theta_{k j}-\gamma_{k} \psi_{i}, k=1 \div 11
\end{aligned}
$$

where $\beta_{\text {ind }}, v_{\text {ind }}, \beta_{\text {exp }}$ are parameters associated with interrelations between performance, managerial independence and export orientation; $\lambda_{\text {ebtrev }}, \lambda_{\text {ebtass }}, \lambda_{\text {expr }}, \lambda_{\text {expgr }}, \gamma_{k}$ are the factor loadings that show how observed indicators determine scores of latent constructs; $\delta_{l s p}, \delta_{\text {fins }}, \delta_{\text {for }}$ are parameters related to the effects of ownership and board composition on managerial independence; $\beta_{\text {empl }}, \beta_{\text {sector }}, \beta_{\text {poland }}$ are the coefficients for the effects of control variables; $\alpha, k_{i}$ are the intercepts. Equations (2e) include unknown threshold parameters, and they specify proportional-odds models for the eleven ordinal indicators of managerial independence $y_{k}$ with observed categories $j_{k}$ and factor loadings $\gamma_{k}$ (see Agresti, 1986, and Congdon, 2003).

To ensure identifiability, we defined the three latent variables $\left(\psi_{i}, \eta_{i}, \xi_{\mathrm{i}}\right)$ as normally distributed with variances of unity. We also allowed for the monotonicity constraint for thresholds $\theta_{k j}$ and their ordering by setting truncated standard normal prior distributions with zero means and large variances. Since in the Gibbs sampling context the predetermined variance identifiability constraint can lead to a problem of "relabelling” of the latent construct scores during the sampling, we followed Congdon (2003) and restricted normal priors with zero means and large variances for factor loadings and parameters $\beta_{\text {ind }}, \beta_{\exp } v_{\text {ind }}$, to positive values.

We verified the convergence of the MCMC simulation using the Gelman-Rubin scale reduction factor (SRF) for a two-chain run (Gelman, 1996). We also verified the 
model's goodness-of-fit by calculating the posterior $p$-value (tail-area) probabilities from the posterior predictive replications (see Gelman, 1996, and Gelman et al., 2004, for a detailed discussion of the construction and computation of the Bayesian $\chi^{2}$ test). The

posterior predictive $p$-value based on the likelihood-ratio test statistic and 2,000 predictive replications was equal to 0.227 , confirming a good fit between our model and the data (Scheines et al. 1999).

\section{Results}

Table 1 provides the definitions of variables used in this study and the descriptive analysis of our data. 68 percent of companies were from the manufacturing sectors, with 32 percent being from services and construction. Mean employment level in our sample was 1063, but the distributions were skewed due to the presence of a few very large companies, especially in the Hungarian sub-sample, where the largest company had 15,599 employees. The distributions of two alternative measures of size, e.g., assets and total revenues, followed a similar pattern. Based on the full sample, the mean value of total revenues was US\$65.5 million while the mean book value of total assets was US\$42.8 million. In terms of corporate governance parameters, almost half of the firms in Hungary and Poland had foreign owners as the largest shareholders. With regard to the proportion of shares held by the largest owner, our data indicates a relatively high level of share-ownership concentration, e.g., 62.5 percent of the total equity. Foreign directors on average held almost a third of board seats. 
Table 1. Variables and Descriptive Statistics

\begin{tabular}{|c|c|c|c|}
\hline Variable & Definition & Mean & Std. Dev. \\
\hline \multicolumn{4}{|c|}{ Performance } \\
\hline ebtrev & Earnings before taxes over sales, \% & 2.16 & 8.83 \\
\hline ebtass & Earnings before taxes over assets, \% & 0.022 & 0.17 \\
\hline \multicolumn{4}{|c|}{ Export orientation } \\
\hline $\operatorname{expr}$ & Export revenue as \% of total sales & 0.25 & 0.28 \\
\hline $\operatorname{expgr}$ & Change in export sales over $1998-2000, \%$ & 1.93 & 10.41 \\
\hline \multicolumn{4}{|c|}{ Managers' independence factors } \\
\hline$y_{1}$ & product mix & 5.54 & 1.89 \\
\hline$y_{2}$ & selection of customers & 5.52 & 1.67 \\
\hline$y_{3}$ & selection of suppliers & 4.77 & 2.16 \\
\hline$y_{4}$ & investment & 4.54 & 2.10 \\
\hline$y_{5}$ & research and development & 4.77 & 2.11 \\
\hline$y_{6}$ & finances & 5.42 & 1.72 \\
\hline$y_{7}$ & employment issues & 5.65 & 1.72 \\
\hline$y_{8}$ & wages & 5.58 & 1.70 \\
\hline$y_{9}$ & management and organization & 5.42 & 1.97 \\
\hline$y_{10}$ & price policy and marketing & 5.52 & 1.86 \\
\hline$y_{11}$ & choice of trade partners & 4.94 & 2.18 \\
\hline \multicolumn{4}{|c|}{ Corporate governance } \\
\hline lsp & Proportion of shares held by the largest shareholder, \% & 62.46 & 32.60 \\
\hline for & Proportion of foreign investors' representatives on board, \% & 31.12 & 36.41 \\
\hline \multicolumn{4}{|c|}{ Control variables } \\
\hline$x_{\text {poland }}$ & Dummy variable for Polish firms & 0.64 & \\
\hline$x_{l a b}$ & Labor intensive industry (ISIC: $15-20$ and 36) & 0.36 & 0.48 \\
\hline$x_{\text {res }}$ & Resource intensive industry (ISIC: 21-26) & 0.21 & 0.41 \\
\hline$x_{\text {tech }}$ & Medium and high technology industry (ISIC: 28-35) & 0.06 & 0.22 \\
\hline$x_{\text {ser }}$ & Services and construction (ISIC: 45, 50-52, > 55) & 0.34 & 0.47 \\
\hline$x_{\text {empl }}$ & Number of employees & 1063 & 1771 \\
\hline fins & Largest shareholder is a foreign investor, a dummy variable & 0.46 & 0.50 \\
\hline
\end{tabular}

Table 2 provides the results of SEM estimations of inter-relationships between governance, strategic independence and performance. According to the results of the measurement models for the three latent variables, strategic independence proxies were within the credible intervals, and they generated a robust latent variable $\left(\psi_{i}\right)$. Similarly, 
the export performance and financial performance proxies were also within credible intervals, and they generated the corresponding latent variables ( $\eta_{i}$, and $\xi_{\mathrm{i}}$ ).

Table 2. Structural Equation Modeling Results

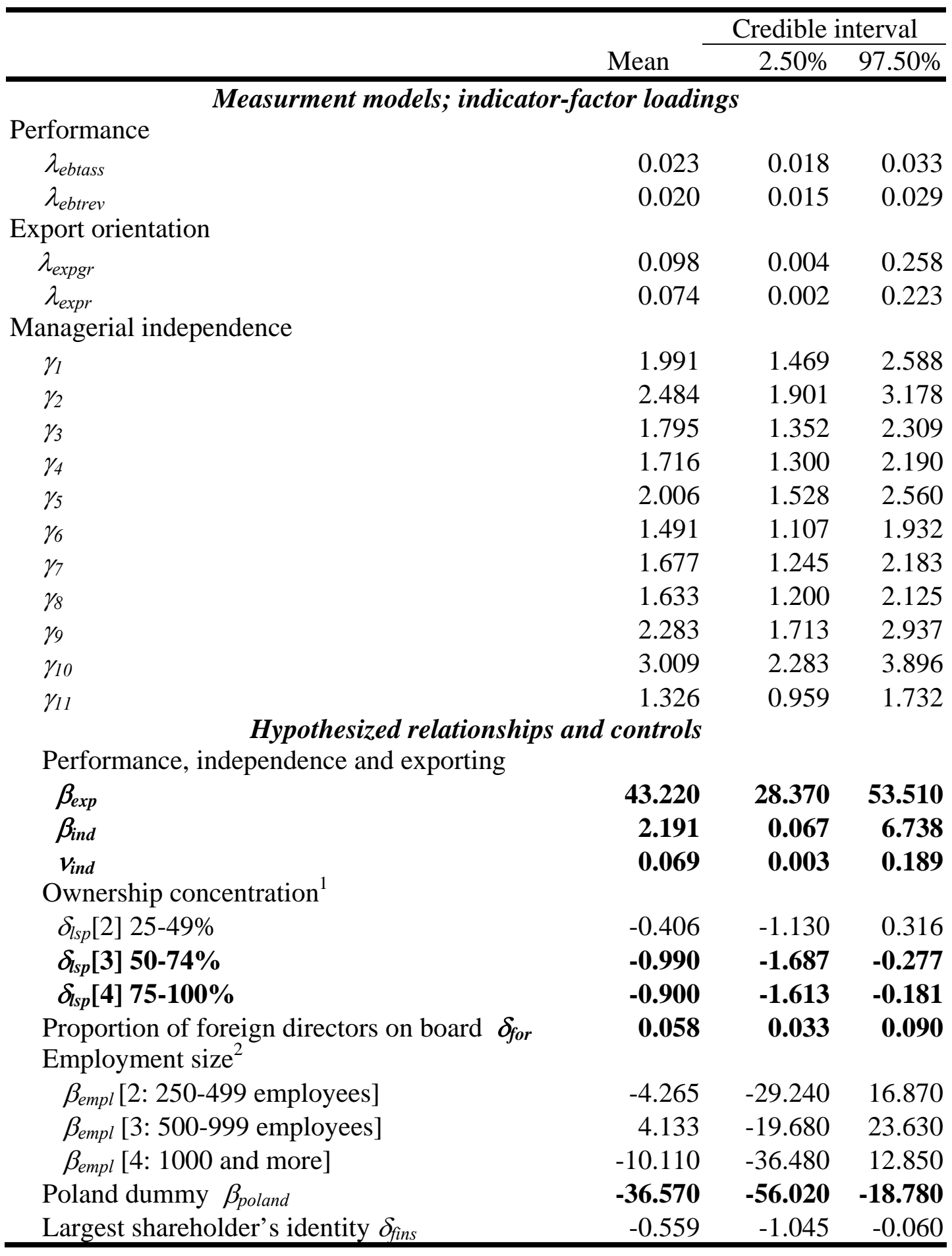


NOTES: Highlighted coefficients (in bold) suggest the 5\% level of significance. Sectoral dummies (all insignificant) and the intercepts are not included in the table.

1. Coefficients for ownership concentration are contrasts with a group where the largest shareholder owns $24 \%$ of shares and less.

2. Coefficients are contrasts with a group of firms with 250 employees and less.

3. Coefficients are contrasts with heavy industry as a reference group.

SEM results generally supported our hypotheses with regard to the interrelationships between managers' strategic independence, export- and financialperformance. In particular, the strategic independence construct was positively associated with export orientation (the coefficient $v_{\text {ind }}$ ) and financial performance (the coefficient $\left.\beta_{\text {ind }}\right)$. These results support hypotheses 1 and 2 . In addition, export orientation was positively associated with the latent variable for financial performance (the coefficient $\beta_{\text {exp }}$ ), and this confirms hypothesis 3. Finally, in terms of the controls, Polish firms significantly under performed their Hungarian counterparts, as indicated by the coefficient $\left(\beta_{\text {poland }}\right)$. The firm's size and sector affiliation did not have any effects on performance.

In terms of corporate governance effects on strategic independence, the SEM results for ownership concentration suggested that there was a negative effect of blockholders on strategic flexibility, but it was significant only at very high levels of concentration: the coefficients $\left(\delta_{l s p}\right)$ were negative and within the confidence interval for (50-74\%) and (75-100\%) ownership ranges, i.e., the levels of ownership that are above the controlling stake, in line with hypothesis 4 . The coefficient for the proportion of foreigners on board $\left(\delta_{f o r}\right)$ was within the confidence intervals, and it was positively associated with the strategic independence construct, in line with hypothesis 5 . In addition, the SEM results provided evidence of a negative but insignificant relationship 
between the strategic independence construct and the dummy variable for the foreign largest shareholder $\left(\delta_{\text {fins }}\right)$.

\section{Discussion and conclusions}

Our study is one of the first examining simultaneous links between corporate governance, managerial independence, exporting and financial performance. The paper helps to fill gaps in relation to multi-industry samples and larger newly-privatized manufacturing firms. It shows that managerial independence in terms of strategic decision-making may play a crucial role as the driver of internationalization and performance. The extent of managerial independence is determined by the general governance factors, such as ownership and board structures. It has been argued that high ownership concentration in transitional economies was investors' response to low levels of protection of minority shareholders in emerging markets (La Porta et al., 1997). However, by early 2000s, the quality of the legal environment improved and we argue that while the presence of concentrated owners could initially result in firm's competitive advantage, it is likely that ten years after the reform program was implemented, the negative effects of private benefit extraction via pyramidal structures mail prevail (Morck et al. 2005). Not only we find supporting evidence for this, but also, we identify the missing link between ownership and performance, which is managerial independence. In particular, restrictions on managerial independence may have negative effects on the

firm's internationalization and performance. Although we focus specifically on Poland and Hungary, variations in governance regimes (La Porta et al., 1997) suggest scope for 
international analyses of the links between governance, strategic independence and performance.

As discussed above, following the privatisation process, control of large enterprises in both Hungary and Poland was frequently passed to corporate investors (in early 1990s). Empirical studies, which focused on the direct link between the ownership and the firm performance were finding a positive relationship between the presence of controlling corporate ('strategic’) investors and performance (see Djankov and Murrell 2002 for a meta-study summarizing this early research). The positive link was typically explained from the resource-based perspective. New corporate owners could offer financial resources needed for restructuring (overcoming initial financial constraints), access to know-how, marketing and organisational skills.

Arguably however, those advantages were temporary. In a market-, competitive environment, all companies have capacity for organisational learning, and - as reforms were gradually implemented - both access to finance and other-resources could be acquired on market basis, without necessity of associating the provision of resources with dominant ownership of the firm. In contrast, with better-functioning capital markets, those who provided the resources could be sufficiently awarded with minority blocks of shares. However, in cases, where the corporate investor retained the dominant position, the acquired companies were simply placed at some lower level of pyramidal ownership structures; the position, which is frequently associated with lower performance, due to the extraction of private benefits by dominant owners (see Morck et al. 2005 and further references therein). Low profitability may be seen as a sign of this, consistent with our findings. 
In addition, the effects of board representation on export- and performanceenhancing strategic independence of managers may have important implications for both the strategy and the exporting literature. Our research suggests that foreign investors' board involvement is playing a relatively more important strategic role than the size of their equity stakes in local firms. This finding is consistent with resource and strategy views on corporate governance that suggest that, in addition to control functions, external board members may also play service/resource roles in the decision-making process (Baysinger and Hoskisson, 1990), especially when the firm faces a highly uncertain environment of institutional transition (Peng, 2004). Our evidence suggests that in transition economies foreign board members may have a positive impact on the extent of managerial independence, which, in turn, underpins exporting and performance.

In addition, we have found evidence of significant positive link between exporting and financial performance in the two transition economies. Exporting, however, is the first stage in the firm's internationalization path (Bernard and Jensen, 1999). As the integration of Poland and Hungary into the EU proceeds, performance differences between exporting and non-exporting firms may affect their subsequent internationalization decision. The longer-term analysis of their strategic dynamics may shed new light on complex inter-relationships between corporate governance, business strategy and performance. 


\section{References}

Agresti, A. An Introduction to Categorical Data Analysis. New York: Wiley, 1996.

Andersen, O. On the Internationalization Process of Firms: A Critical Analysis. Journal of International Business Studies 1993; 24 (2): 209-231.

Aulakh P. Masaaki K. Teegen H. Export Strategies and Performance of Firms From Emerging Economies: Evidence From Brazil, Chile and Mexico. Academy of Management Journal 2000; 43 (3): 342-361.

Baysinger BD. Hoskisson RE. The Composition of Boards of Directors and Strategic Control: Effects on Corporate Strategy. Academy of Management Review 1990; 15 (1): 72-87.

Bernard AB. Jensen JB. Exceptional Exporter Performance: Cause, Effect, or Both? Journal of International Economics 1999; 47: 1-25.

Clerides SK. Lach S. Tybout JR. Is Learning by Exporting Important, Micro-Dynamic Evidence from Colombia, Mexico and Morocco. Quarterly Journal of Economics 1998; 113: $903-48$.

Congdon P. Applied Bayesian Modelling. Chichester: John Wiley \& Sons, 2003.

Djankov S. Murrell P. Enterprise Restructuring in Transition: A Quantitative Survey. Journal of Economic Literature 2002; 40 (3): 739-792.

Finney R. Campbell N. Powell M. Strategies and Resources: Pathways to success? Journal of Business Research 2005; 58: 1721-1729.

Gelman A. Inference and Monitoring Convergence. In Gilks WR. Richardson S. Spiegelhalter D, editors. Markov Chain Monte Carlo in Practice. London: Chapman \& Hall, 1996. pp. 131-143.

Gelman A. Carlin JB. Stern HS. Rubin DB. Bayesian Data Analysis. $2^{\text {nd }}$ ed. London: Chapman \& Hall/CRC, 2004.

Gilks WR. Richardson S. Spiegelhalter D. Introducing Markov Chain Monte Carlo. In Gilks WR. Richardson S. Spiegelhalter D, editors. Markov Chain Monte Carlo in Practice. London: Chapman \& Hall, 1996. pp. 1-19.

Harrigan KR. Strategic Flexibility: A Management Guide for Changing Times. Lexington, MA: Lexington Books, 1985.

Hitt M. Keats BW. DeMarie SM. Navigating in the New Competitive Landscape: Building Strategic Flexibility and Competitive Advantage in the $21^{\text {st }}$ Century. Academy of Management Executive 1998; 12 (4): 22-42.

Hoskisson RE. Eden L. Lau C.-M. Wright M. Strategy in Emerging Economies. Academy of Management Journal 2000. 43 (3): 249-267.

Kornai J. Economics of Shortage. Amsterdam: North Holland, 1980.

La Porta R. Lopez-de-Silanes F. Shleifer A. Vishny R. Legal Determinants of External Finance. Journal of Finance 1997; 52 (3): 1131-1150. 
Luo Y. Peng M. Learning to Compete in a Transition Economy: Experience, Environment and Performance. Journal of International Business Studies 1999; 30 (2): 269-296.

Mahoney JT. The Management of Resources and the Resource of Management. Journal of Business Research 1995; 33: 91-102.

Makhija MV. The Value of Restructuring in Emerging Economies: the Case of Czech Republic. Strategic Management Journal 2004; 25: 243-267.

Maug E. Large Shareholders as Monitors: Is There a Trade-Off Between Liquidity and Control? Journal of Finance 1998; 53: 65-92.

Mickiewicz, T. Economic Transition in Central Europe and the Commonwealth of Independent States. Houndmills: Palgrave-Macmillan, 2005.

Randal Morck R. Wolfenzon D. Yeung B. Corporate Governance, Economic Entrenchment, and Growth. Journal of Economic Literature 2005.

Newman K. Organizational Transformation During Institutional Upheaval. Academy of Management Review 2000; 25: 602-619.

Peng M. Outside Directors and Firm Performance During Institutional Transitions. Strategic Management Journal 2004; 25: 453-471.

Sanchez R. Strategic Flexibility in Product Competition, Strategic Management Journal 1996; 16: 135-159.

Sanders G. Carpenter M. Internationalization and Firm Governance: The Roles of CEO Compensation, Top Team Composition, and Board Structure. Academy of Management Journal 1998; 41: 158-178.

Scheines R. Hoijtink H. Boomsma A. Bayesian Estimation and Testing of Structural Equation Models. Psychometrika 1999; 64: 37-52.

Spiegelhalter D. Thomas A. Best N. WinBUGS, Version 1.3 User Manual. Cambridge, UK: MRS Biostatistics Unit, 2000.

Uhlenbruck, K. Meyer K. Hitt MA. Organizational Transformation in Transition Economies: Resource-based and Organizational Learning Perspectives. Journal of Management Studies 2003; 40 (2): 257-282. 


\section{WILLIAM DAVIDSON INSTITUTE WORKING PAPER SERIES}

The Working Paper Series may be downloaded free of charge at: www.wdi.umich.edu

CURRENT AS OF 3/1/06

\begin{tabular}{|c|c|c|}
\hline Publication & Authors & Date \\
\hline $\begin{array}{l}\text { No. 805: Corporate Governance, Managers’ Independence, Exporting \& } \\
\text { Performance in Firms in Transition Economies }\end{array}$ & $\begin{array}{l}\text { Igor Filatotchev, Natalia } \\
\text { Isachenkova and Tomasz } \\
\text { Mickiewicz }\end{array}$ & Nov. 2005 \\
\hline $\begin{array}{l}\text { No. 804: Financial Deregulation \& Economic Growth in the Czech } \\
\text { Republic, Hungary and Poland }\end{array}$ & Patricia Mc Grath & Nov. 2005 \\
\hline $\begin{array}{l}\text { No. 803: Evaluating the Causal Effect of Foreign Acquisition on Domestic } \\
\text { Performances: The Case of Slovenian Manufacturing Firms }\end{array}$ & Sergio Salis & Jan. 2006 \\
\hline No. 802: Implications of ERM2 for Poland's Monetary Policy & $\begin{array}{l}\text { Lucjan T. Orlowski and } \\
\text { Krzysztof Rybinski }\end{array}$ & Dec. 2005 \\
\hline $\begin{array}{l}\text { No. 801: Original Sin, Good Works, and Property Rights in Russia: } \\
\text { Evidence From a Survey Experiment }\end{array}$ & Timothy Frye & Sept. 2005 \\
\hline $\begin{array}{l}\text { No. 800: Fiscal Reform \& Its Firm-Level Effects in Eastern Europe \& } \\
\text { Central Asia }\end{array}$ & John Anderson & Aug. 2005 \\
\hline $\begin{array}{l}\text { No. 799: Bond Yield Compression in the Countries Converging to the } \\
\text { Euro }\end{array}$ & $\begin{array}{l}\text { Lucjan Orlowski and Kirsten } \\
\text { Lommatzsch }\end{array}$ & Oct. 2005 \\
\hline $\begin{array}{l}\text { No. 798: Contagion Across \& Integration of Central \& Eastern European } \\
\text { Stock Markets: Evidence from Intraday Data }\end{array}$ & Balazs Egert and Evzen Kocenda & Nov. 2005 \\
\hline No. 797: Real Exchange Rate Misalignment: Prelude to Crisis? & David Kemme and Saktinil Roy & Oct. 2005 \\
\hline $\begin{array}{l}\text { No. 796: Balassa-Samuelson Meets South Eastern Europe, the CIS and } \\
\text { Turkey: A Close Encounter of the Third Kind? }\end{array}$ & Balázs Égert & Nov. 2005 \\
\hline $\begin{array}{l}\text { No. 795: A Comparison of Reform-Era Labor Force Participation Rates of } \\
\text { China's Ethnic Minorities and Han Majority }\end{array}$ & $\begin{array}{l}\text { Margaret Maurer-Fazio, James } \\
\text { W. Hughes and Dandan Zhang }\end{array}$ & Oct. 2005 \\
\hline $\begin{array}{l}\text { No. 794: Collective Action and Post-Communist Enterprise: } \\
\text { The Economic Logic of Russia’s Business Associations }\end{array}$ & William Pyle & Sept. 2005 \\
\hline $\begin{array}{l}\text { No. 793: Equilibrium Exchange Rates in Transition Economies: } \\
\text { Taking Stock of the Issues }\end{array}$ & Balázs Égert & Oct. 2005 \\
\hline No. 792: Bribery: Who Pays, Who Refuses, What Are The Payoffs? & Jennifer Hunt and Sonia Laszlo & Sept. 2005 \\
\hline $\begin{array}{l}\text { No. 791: Gender Differences In Personality and Earnings: Evidence from } \\
\text { Russia }\end{array}$ & $\begin{array}{l}\text { Susan Linz and Anastasia } \\
\text { Semykina }\end{array}$ & Apr. 2005 \\
\hline No. 790: Why Are Some Public Officials More Corrupt Than Others? & Jennifer Hunt & Sept. 2005 \\
\hline No. 789: Disinflation and Monetary Policy Arrangements in Romania & Daniel Daianu and Ella Kalai & Nov. 2004 \\
\hline $\begin{array}{l}\text { No. 788: Does Economic Uncertainty Affect the Decision to Bear } \\
\text { Children? Evidence from East and West Germany }\end{array}$ & $\begin{array}{l}\text { Sumon Kumar Bhaumik and } \\
\text { Jeffrey B. Nugent }\end{array}$ & Aug. 2005 \\
\hline $\begin{array}{l}\text { No. 787: Economic Reform and Changing Patterns of Labor Force } \\
\text { Participation in Urban and Rural China }\end{array}$ & $\begin{array}{l}\text { Margaret Maurer-Fazio, James } \\
\text { Hughes and Dandan Zhang }\end{array}$ & Aug. 2005 \\
\hline $\begin{array}{l}\text { No. 786: The Determinants of Asset Stripping: Theory and Evidence From } \\
\text { the Transition Economies }\end{array}$ & $\begin{array}{l}\text { Nauro F. Campos and Francesco } \\
\text { Giovannoni }\end{array}$ & Aug. 2005 \\
\hline $\begin{array}{l}\text { No. 785: How to Catch Foreign Fish? FDI and Privatization in EU } \\
\text { Accession Countries }\end{array}$ & $\begin{array}{l}\text { Bruno Merlevede and Koen } \\
\text { Schoors }\end{array}$ & Aug. 2005 \\
\hline $\begin{array}{l}\text { No. 784: Does the World Bank have any impact on human development of } \\
\text { the poorest countries? Some preliminary evidence from Africa }\end{array}$ & Sumon Kumar Bhaumik & Aug. 2005 \\
\hline $\begin{array}{l}\text { No. 783: Comparative social capital: Networks of entrepreneurs and } \\
\text { investors in China and Russia }\end{array}$ & Bat Batjargal & July 2005 \\
\hline $\begin{array}{l}\text { No. 782: Exchange Rate Regimes, Foreign Exchange Volatility and } \\
\text { Export Performance in Central and Eastern Europe: Just Another Blur } \\
\text { Project? }\end{array}$ & $\begin{array}{l}\text { Balázs Égert and Amalia } \\
\text { Morales-Zumaquero }\end{array}$ & July 2005 \\
\hline $\begin{array}{l}\text { No. 781: Equilibrium Exchange Rate in the Czech Republic: How Good is } \\
\text { the Czech BEER? }\end{array}$ & Ian Babetskii and Balázs Égert & July 2005 \\
\hline $\begin{array}{l}\text { No. 780: Autonomy and Performance of Foreign Subsidiaries in five } \\
\text { Transition Countries }\end{array}$ & $\begin{array}{l}\text { Urmas Varblane, Katrin Männik, } \\
\text { and Helena Hannula }\end{array}$ & July 2005 \\
\hline
\end{tabular}

